\title{
Mystery Case: Cowden syndrome presenting with paraneoplastic encephalitis
}

Meng-sha Yao, MD, Sheng Chen, MD, PhD, and Jun Liu, MD, PhD

Neurology ${ }^{\circledR}$ 2019;93:813-815. doi:10.1212/WNL.0000000000008398
Correspondence

Dr. Chen

mztcs@163.com

Figure Clinic findings of the patient indicating Cowden syndrome

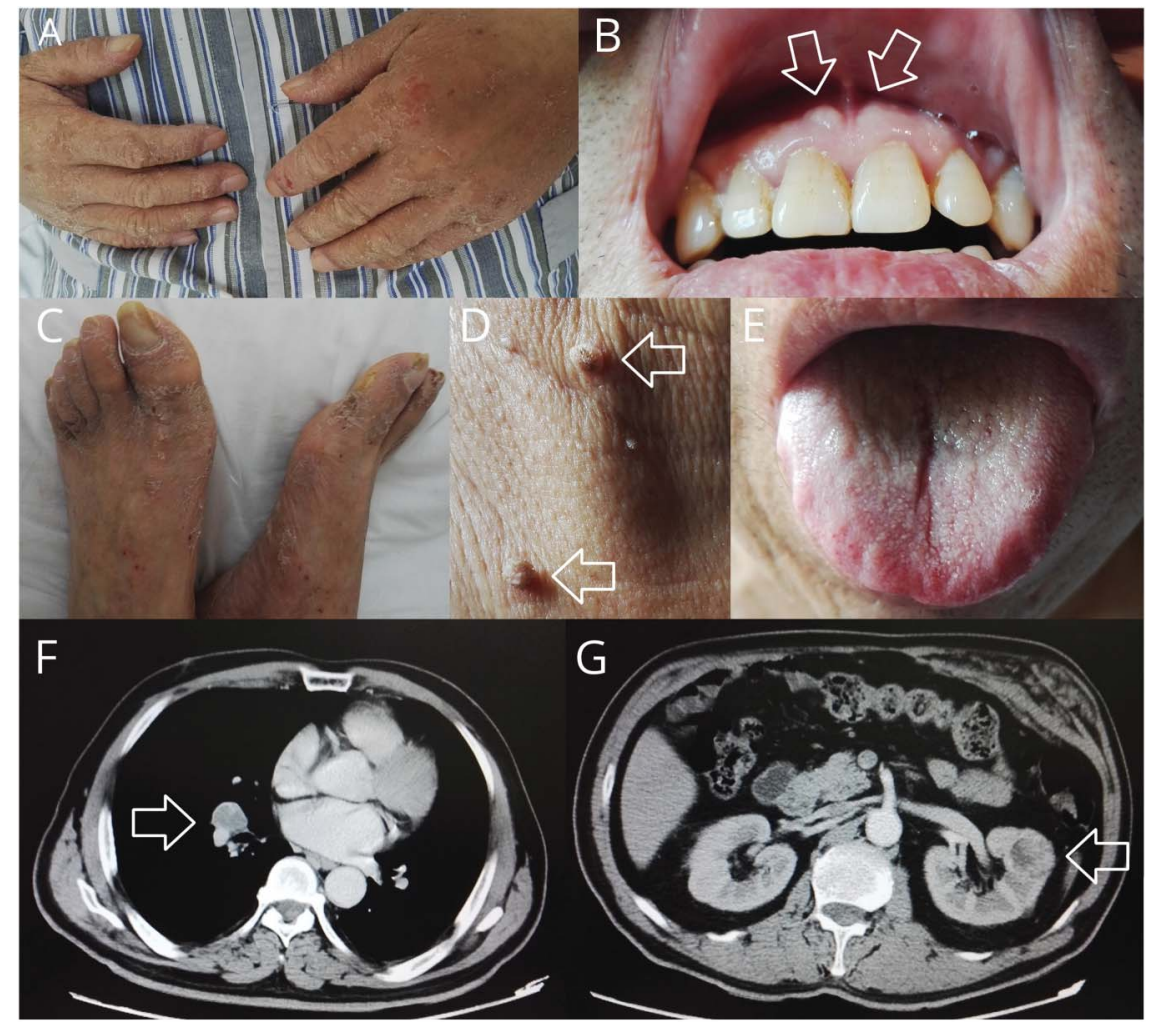

Acrokeratosis of the fingers and toes $(A, C)$, mucocutaneous papillomatosis around the gingiva and neck (B, D), and fissured tongue (E) constituted specific skin changes. Enhanced CT showed malignant tumors in lung and kidney $(F, G)$.
A 64-year-old man complained of progressive memory loss for 12 days. Neurologic examination indicated moderate cognitive decline. Autoimmune antibody testing showed that both AMPAR and NMDA receptor (NMDAR) antibodies were positive in serum and CSF. Paraneoplastic encephalitis was diagnosed initially. Further evaluations confirmed 2 malignant tumors including lung small cell carcinoma, renal clear cell carcinoma, and multiple benign tumors including abdominal wall hamartoma, colon adenoma with severe atypical hyperplasia, and multiple cysts in liver and kidney. Further physical examination showed macrocephaly and multiple mucocutaneous lesions including acrokeratosis, fissured tongue, and mucocutaneous papillomatosis around his gingiva and neck (figure). Whole-exome sequencing test via nextgeneration sequencing identified a pathogenic heterozygous mutation c.438delC in the KLLN gene. Cowden syndrome (CS) was diagnosed.

\section{MORE ONLINE}

Survey and results

NPub.org/mc9318

From Shanghai Jiao Tong University School of Medicine (M.-s.Y.); and Department of Neurology (S.C., J.L.), Shanghai Ruijin Hospital, Affiliated Hospital of Shanghai Jiao Tong University School of Medicine, Shanghai, China.

Go to Neurology.org/N for full disclosures. Funding information and disclosures deemed relevant by the authors, if any, are provided at the end of the article. 
CS is a rare autosomal dominant inherited disease characterized by increased incidence of malignant tumors in multiple organs especially breast, thyroid, and genitourinary system. Mucocutaneous lesions such as acrokeratosis, facial trichilemmomas, and oral mucosal papillomatosis are the most specific features in CS, as well as neurologic manifestations including Lhermitte-Duclos disease, macrocephaly, mental retardation, intellectual impairment, and intracranial vascular malformation. ${ }^{1}$ Cowden-like syndrome (CS-like, CSL) shares some clinical features of CS, but does not meet all of the clinical diagnostic criteria for CS. Both PTEN gene mutation and KLLN gene promoter hypermethylation are associated with CS/CSL. ${ }^{2}$ KLLN gene point mutation as in this patient has not been well-described and needs further study. It is recommended that patients with CS without germline PTEN mutations should be offered KLLN gene testing for seeking promoter methylation. In addition, CS should be differentiated from Bannayan-Riley-Ruvalcaba syndrome (BRRS). Although BRRS is also included in the PTEN hamartoma tumor syndrome, BRRS is not considered to increase the risk for cancer. ${ }^{3}$ In this case, we considered that the rapid cognitive decline was caused by paraneoplastic encephalitis. However, multiple tumors were caused by CS.

\section{Study funding}

This work was supported by grants from the National Natural Sciences Foundation of China (81671241).

\section{Disclosure}

The authors report no disclosures relevant to the manuscript. Go to Neurology.org/N for full disclosures.

Appendix Authors

\begin{tabular}{|c|c|c|c|}
\hline Name & Location & Role & Contribution \\
\hline $\begin{array}{l}\text { Meng- } \\
\text { sha } \\
\text { Yao, } \\
\text { MD }\end{array}$ & $\begin{array}{l}\text { Shanghai Jiao Tong } \\
\text { University School of } \\
\text { Medicine, Shanghai, } \\
\text { China }\end{array}$ & Author & $\begin{array}{l}\text { Gathered data, edited } \\
\text { pictures, wrote } \\
\text { manuscript }\end{array}$ \\
\hline $\begin{array}{l}\text { Sheng } \\
\text { Chen, } \\
\text { MD, } \\
\text { PhD }\end{array}$ & $\begin{array}{l}\text { Department of } \\
\text { Neurology, Shanghai } \\
\text { Ruijin Hospital, Affiliated } \\
\text { Hospital of Shanghai Jiao } \\
\text { Tong University School of } \\
\text { Medicine, Shanghai, } \\
\text { China }\end{array}$ & Author & $\begin{array}{l}\text { Gathered data, } \\
\text { designed and revised } \\
\text { manuscript }\end{array}$ \\
\hline $\begin{array}{l}\text { Jun Liu, } \\
\text { MD, } \\
\text { PhD }\end{array}$ & $\begin{array}{l}\text { Department of } \\
\text { Neurology, Shanghai } \\
\text { Ruijin Hospital, Affiliated } \\
\text { Hospital of Shanghai Jiao } \\
\text { Tong University School of } \\
\text { Medicine, Shanghai, } \\
\text { China }\end{array}$ & Author & $\begin{array}{l}\text { Participated in the } \\
\text { diagnosis and } \\
\text { treatment process, } \\
\text { revised manuscript }\end{array}$ \\
\hline
\end{tabular}

\section{References}

1. Farooq A, Walker LJ, Bowling J, Audisio RA. Cowden syndrome. Cancer Treat Rev 2010;36:577-583.
2. Bennett KL, Mester J, Eng C. Germline epigenetic regulation of KILLIN in Cowden and Cowden-like syndrome. JAMA 2010;304:2724-2731.

3. Pilarski R, Eng C. Will the real Cowden syndrome please stand up (again)? Expanding mutational and clinical spectra of the PTEN hamartoma tumour syndrome. J Med Genet 2004;41:323-326.

\section{Mystery Case Responses: 64-year-old man with rapid-onset dementia}

The Mystery Case series was initiated by the Neurology ${ }^{\circledR}$ Resident \& Fellow Section to develop the clinical reasoning skills of trainees. Residency programs, medical student preceptors, and individuals were invited to use this Mystery Case as an educational tool. Responses to multiple-choice questions formulated using this case were solicited through a group email sent to the American Academy of Neurology Consortium of Neurology Residents and Fellows and through social media. We received 440 responses. The majority of respondents $(64 \%)$ had been in practice for $1-4$ years; $53 \%$ were residents or fellows while $36 \%$ were faculty/boardcertified physicians; the remainder were medical students or advanced practice providers. A total of $71 \%$ resided outside the United States. A wide range of practice settings and countries was represented.

When presented with this brief vignette about a 64-year-old man with rapid-onset dementia and asked to prioritize the next steps in the evaluation, $92.3 \%$ correctly chose brain MRI, $84.3 \%$ correctly chose autoimmune/paraneoplastic encephalitis antibodies, and $40.2 \%$ correctly chose RT-QuIC test. The most frequently selected incorrect options were CSF $\beta$-amyloid and tau biomarkers (21.1\%) and CSF neurotransmitters (13.4\%). Although $\beta$-amyloid and tau biomarkers are an important part of dementia evaluation, the other options are more likely to have a higher yield in rapid-onset dementia. Neurotransmitter abnormalities usually present during the pediatric years and have additional findings like seizures or abnormal movements.

After being given the results showing a positive AMPAR and NMDAR antibodies in serum and CSF, participants were asked to choose the next tests they would consider first. The majority of respondents correctly chose chest, abdomen, and pelvis CT (80.5\%), whole-body PET (60.7\%), and testicular ultrasonography (52.0\%). The main diagnostic focus in a patient this age with the mentioned antibodies should be to rule out a malignancy. CSF cytology and flow cytometry (40.7\%) and whole-spine MRI (10.9\%) were also frequently chosen answers. Although these are important tests for CNS malignancy, most of the time, AMPAR and NMDAR are associated with disease outside the nervous system.

Finally, additional information regarding clinical findings and types of tumors found was given to the participants, who were asked to choose their main diagnosis. CS was correctly chosen by $23.6 \%$ of the respondents. Common but incorrect answers were Li-Fraumeni syndrome (23.6\%), Peutz-Jeghers syndrome (15.7\%), and neurofibromatosis type $1(14.8 \%)$. CS is an autosomal dominant hereditary cancer syndrome. The most 
common cause is PTEN mutations (in $80 \%$ of patients), but mutations in SDHB/C/D, PIK3CA, AKT1, and KLLN have also been described. There are certain characteristics that should raise strong clinical suspicion of Cowden disease, including Lhermitte-Duclos disease (dysplastic cerebellar gangliocytoma), extreme macrocephaly, oral mucosa papillomatosis, and penile freckling. ${ }^{1}$
Alonso Zea Vera, MD

Cincinnati Children's Hospital Medical Center

\section{Reference}

1. Mester J, Eng C. Cowden syndrome: recognizing and managing a not-so-rare hereditary cancer syndrome. J Surg Oncol 2015;111:125-130.

\section{Apply for 2020 Live Well, Lead Well Programs by November 29}

There's still time to help build a community of wellness leaders by applying for one of two unique well-being and resiliencecultivating programs in conjunction with the 2020 Annual Meeting in Toronto: Live Well, Lead Well: Improve Your Practice Culture or Live Well, Lead Well: Influence Your Program. Visit AAN.com/view/lwlw to apply before November 29-and encourage a colleague who is interested in being a well-being champion to apply, too!

\section{The AAN Has Your Back!}

Every day, the AAN is fighting for you. From actively lobbying members of Congress for common sense legislation, to meeting with regulators to demonstrate the value of neurology and reduce regulatory hassles, the Academy is forcefully countering any threats to your profession and patient access to care. Learn more at AAN.com/policy-and-guidelines/advocacy, read the bimonthly Capitol Hill Report and monthly AANnews member magazine, and respond to Advocacy Action Alert emails when we invite you to share your voice with Congress.

Get into the conversation at \#AANAdvocacy.

\section{Disputes \& Debates: Rapid online correspondence}

The editors encourage comments on recent articles through Disputes \& Debates:

Access an article at Neurology.org/N and click on "COMMENT" beneath the article header. Responses will be posted within 3 business days.

Before submitting a comment to Disputes \& Debates, remember the following:

- Disputes \& Debates is restricted to comments about studies published in Neurology within the last eight weeks

- Read previously posted comments; redundant comments will not be posted

- Your submission must be 200 words or less and have a maximum of five references; reference one must be the article on which you are commenting

- You can include a maximum of five authors (including yourself) 


\section{Neurology}

\section{Mystery Case: Cowden syndrome presenting with paraneoplastic encephalitis}

Meng-sha Yao, Sheng Chen and Jun Liu

Neurology 2019;93;814-816

DOI 10.1212/WNL.0000000000008398

This information is current as of October 28, 2019

\section{Updated Information \& Services}

References

Subspecialty Collections

Permissions \& Licensing

Reprints including high resolution figures, can be found at: http://n.neurology.org/content/93/18/814.full

This article cites 4 articles, 1 of which you can access for free at: http://n.neurology.org/content/93/18/814.full\#ref-list-1

This article, along with others on similar topics, appears in the following collection(s):

\section{All Genetics}

http://n.neurology.org/cgi/collection/all_genetics

Autoimmune diseases

http://n.neurology.org/cgi/collection/autoimmune_diseases

Memory

http://n.neurology.org/cgi/collection/memory

Paraneoplastic syndrome

http://n.neurology.org/cgi/collection/paraneoplastic_syndrome

Information about reproducing this article in parts (figures,tables) or in its entirety can be found online at:

http://www.neurology.org/about/about_the_journal\#permissions

Information about ordering reprints can be found online:

http://n.neurology.org/subscribers/advertise

Neurology ${ }^{\circledR}$ is the official journal of the American Academy of Neurology. Published continuously since 1951, it is now a weekly with 48 issues per year. Copyright (O 2019 American Academy of Neurology. All rights reserved. Print ISSN: 0028-3878. Online ISSN: 1526-632X.

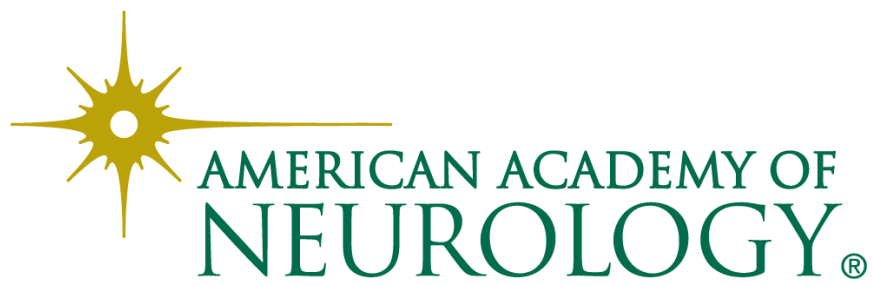

